\title{
Relationship of the Celiac Trunk with Median Arcuate Ligament of the Diaphragm
}

\author{
Relación del Tronco Celíaco con el Ligamento Arqueado Mediano del Diafragma \\ "Selma Petrella; **Celio Fernando de Sousa Rodriguez; ***Emerson Alexandre Sgrott; **** Geraldo José Medeiros Fernandes; \\ ***** Sergio Ricardo Marques \& ${ }^{* * * * *}$ José Carlos Prates
}

PETRELLA, S.; RODRIGUES, C. F. S.; SGROTT, E. A; FERNANDEZ, G. J. M.; MARQUES, S. R. \& PRATES, J. C. Relationship of the celiac trunk with median arcuate ligament of the diaphragm. Int. J. Morphol., 24(2):263-274, 2006.

SUMMARY: In the present study different positions of the median arcuate ligament in relation to the celiac trunk as well as measurements of overlap and distance, also the approach between the two structures were investigated. In addition histological studies of the diaphragm crura and the median arcuate ligament were performed.

Sixty-three cadavers fixed in formalin $10 \%$ aqueous solution and 20 non-fixed adult cadavers of both sexes were studied. Dissections of the celiac trunk were performed after dissection of the peritoneal cavity in the laboratories of the Anatomy Division of the UNIFESPEPM, UNILUS and UNISA, and during necropsies in the City Morgue of the UNIFESP-EPM and USP.

Regarding morphological analysis under light microscopy, three non-fixed cadavers were randomly chose and fragments measuring $5 \mathrm{~cm}$ height versus $2,5 \mathrm{~cm}$ length of the median arcuate ligament were removed and processed according to routine techniques of inclusion. Sections of $5 \mu \mathrm{m}$ were hematoxyline-eosin stained according to Masson's technique.

The results allowed us to conclude the following: 1) the positions of the median arcuate ligament in the celiac trunk were analyzed irrespective of the gender. In $12(14.46 \%)$ out of the 83 cadavers, the celiac trunk was distant from the median arcuate ligament. In $35(42.17 \%)$ cadavers this ligament touched the celiac trunk and in $36(43.37 \%)$ overlaps this vessel. The mean distance between the median arcuate ligament and the celiac trunk was $0.94 \mathrm{~cm}$ and the overlap was $0.42 \mathrm{~cm} ; 2$ ) the histological analysis of the median arcuate ligament showed a dense connective tissue infiltrated by adipose cells, blood vessels and nerves. Striated skeletal muscle fibers intermingled with collagenous fibers was observed in continuity to the tissues above mentioned.

KEY WORDS: Celiac trunk; Ligaments; Syndrome; Diaphragm; Arterial occlusive disease.

\section{INTRODUCTION}

The syndrome of celiac trunk compression (or celiac axis compression syndrome) is a nosologic entity that has been recently introduced in the abdominal vascular pathology field based on the clinical-radiological observations by correlating abdominal symptoms caused by the compression of celiac trunk crura (Dunbar et al., 1965). Since then, several cases have been reported describing this syndrome (Debray \& Leymarios, 1968; Fadhli, 1968; Harjola, 1968; Edwards, 1969; Hivet \& Lagadec, 1970; Stanley \& Fry, 1971; Ciscato et al., 1976; Joubaud et al., 1977; Kokotsakis et al., 2000; Roayaie et al., 2000; Dordoni et al., 2002; Alehan \& Dogan, 2004 and Desmond \& Roberts, 2004).
This syndrome is characterized by the triad abdominal pain, systolic bruit and stenosis of the celiac trunk (Thevenet et al., 1985).

Several studies established a correlation between syndrome suppression and decompression of the celiac trunk due to surgically sectioning of the median arcuate ligament (Bessot et al., 1970) or with a sympathectomy and denervation of the celiac ganglion sectioning the nervous fibers (Snyder et al., 1967), or associating both surgical procedures (Carey et al., 1969; Cormier \& De La Fontaine, 1970 and Hivet \& Lagadec).

* Arbovirus Division, Adolfo Lutz Institute, São Paulo, Brazil.

** Department of Morphology, Federal University of Alagoas, Brazil.

*** Descriptive and Topographic Anatomy Division, Vale do Itajaí University, Santa Catarina, Brazil.

**** Descriptive and Topographic Anatomy Division, Federal University of São Paulo, Brazil. 
Some studies have reported the occurrence of compression associated with origins of the celiac trunk as well as with the superior mesenteric artery by means of the median arcuate ligament of the diaphragm (Gautier-Benóit et al., 1970; Lord et al., 1968; Edwards; Broussin et al., 1970; Curl et al., 1971; Mulder et al., 1971; Stanley \& Fry; Watt, 1972; Daily \& Fogarty, 1976; Watson \& Sadikali, 1977; Houssin et al., 1979; Langeron et al., 1980; Ghosn et al., 1982; Rogers et al., 1982; Bacourt et al., 1984; Lawson \& Ochsner; Thevenet et al.; Bacourt et al., 1988 and Loffeld et al., 1995).

The physiopathological mechanisms of the pain in the compression of celiac trunk syndrome are not very clear and two theories have been proposed: the ischemic and the neurogenic theories (Thevenet et al.). It had been long asked if the syndrome really exists causing abdominal pain (Szilagyi et al., 1972; Evans, 1974; Brandt \& Boley, 1978; Croft et al., 1981 and Plate et al., 1981) although the beneficial effects of the surgical incision of the median arcuate ligament indicate a correlation between abdominal pain and the stenosis angiographically observed (Edhag et al., 1977 and Lawson \& Ochsner).

Although the real frequency of this syndrome is still unknown and many cases are randomly discovered (Huguet et al., 1972) its occurrence is frequent (Warter et al., 1969; Warter et al., 1970a and Colapinto et al., 1972). It is considered a real pathological entity whose surgical treatment is susceptible to ensure healing at long term in approximately $80 \%$ to $86 \%$ of the cases (Olivier et al., 1970; Warter et al., 1976 and Tridico et al., 1988).

Our purpose was to conduct a systematic research on this subject based on the observations presented by the authors, mainly in the last decades, almost always clinically or surgically regarding the celiac trunk. We aimed to demonstrate its behavior in relation to diaphragm crura and in particular with the median arcuate ligament or intercrural, trying to provide anatomical data on this syntrophy. Since there are controversies regarding the architecture of the median arcuate ligament, observations based on its structure will be presented under light microscopy.

\section{MATERIAL AND METHOD}

Eighty three cadavers from the following institutions were dissected: Death Verification Service of the Federal University of São Paulo (UNIFESP/EPM), Obituary Service of the city of São Paulo at the Medical University of São Paulo (USP) and Anatomy Laboratories at the Federal University of São Paulo (UNIFESP/EPM), Medical Sciences Faculty of the Lusíada University Center (UNILUS) and the Santo Amaro University (UNISA), Brasil.
Sixty three cadavers fixed in $10 \%$ formalin solution were dissected, with ages ranging from 21 to 82 years, of which 54 were males and nine females and 20 non -fixed cadavers were maintained in a frigorific chamber were also dissected, of which 12 males and eight females, with ages ranging from 34 to 88 years. Dissection processes were performed during necropsies at the Death Verification Service of the city of São Paulo, in the Medical University of São Paulo and in the Death Verification Service of the Federal University of São Paulo, Brazil.

To dissect the celiac trunk and the superior mesenteric artery in the fixed cadavers, the pancreas was removed or had its body sectioned or divided with the aid of a scissor. In nonfixed cadavers, the celiac trunk and the superior mesenteric artery were reached by the omentum, opening the flaccid part of the lesser omentum. Ganglions and the nervous tissue of the celiac plexus, involving the initial segment of the mentioned vessels (celiac trunk and superior mesenteric artery), were withdrawn with the aid of a pincer and scissor to allow observing disposition of these arteries from the origin.

After resection of connective tissue adjacent to the diaphragm crura and also resection of the adhered tissues to the median arcuate ligament contour, these structures were exposed allowing observation of their relationships with the celiac trunk.

Mensuration of the distance between the celiac trunk and the median arcuate ligament.

This distance was assessed in 12 out of the 83 cadavers between the superior margin of the origin of the celiac trunk and the free edge of the median arcuate ligament.

Mensuration of overlap of the median arcuate ligament in the celiac trunk.

The distance of the overlap of median arcuate ligament was assessed in 36 out of 83 cadavers and was obtained in the first centimeters close to the origin of the celiac trunk.

Histological studies. Fragments of the median arcuate ligament measuring $0.5 \mathrm{~cm}$ of height by $1.5 \mathrm{~cm}$ of width of three non- fixed cadavers who were maintained in frigorific chamber were resected and embedded in Bouin's solution and processed according to the methodology established by Masson. The fragments were paraffin embedded and the sections measuring $5 \mu \mathrm{m}$ in thickness were performed. These were submitted to staining methods hematoxylin and eosin and Masson's trichrome method for histological analysis under light microscopy. 
Statistical Analysis (Siegel et al., 1976). To study the possible associations between sexes and the situation of the median arcuate ligament in the celiac trunk, in a type $2 \times 2$ table, the Chi-square test for two independent samples was used.

The rejection level for the null hypothesis was fixed in a value smaller or equal to $0.05 \%(5 \%)$.

When the calculated statistics did not present significance, NS was used to characterize it.

\section{RESULTS}

Situation of the median arcuate ligament in relation to the celiac trunk. The results are shown in Table I.

Table I. Situation of the median arcuate ligament in the celiac axis in cadavers according to gender and result of statistics.

\begin{tabular}{lcccc}
\hline \multirow{2}{*}{ Situation } & Male & Female & Total & Ratio / Males \\
\cline { 2 - 4 } Distant & 9 & 3 & 12 & 0,7500 \\
Tangent & 29 & 6 & 35 & 0,8286 \\
Overlapped & 28 & 8 & 36 & 0,7778 \\
\hline Total & 66 & 17 & 83 & 0,7952 \\
\hline
\end{tabular}

$\mathrm{X}^{2}$ calc. $=0,457 \mathrm{NS}$

The different positions of the median arcuate ligament were analyzed irrespective of the patient's gender. In 12 cadavers $(14.46 \%)$ the median arcuate ligament was distant from the celiac trunk (Fig.1).

The mean distance between the median arcuate ligament and the celiac trunk was $0.94 \mathrm{~cm}$, with a minimum distance of $0.2 \mathrm{~cm}$ and maximum of $2.32 \mathrm{~cm}$. A distance of $0.20 \mathrm{~cm}$ was observed in two cadavers $(16.67 \%), 0.30 \mathrm{~cm}$ in one cadaver $(8.33 \%), 0.38 \mathrm{~cm}$ in one $(8.33 \%), 0.50 \mathrm{~cm}$ in three $(25 \%), 0.7 \mathrm{~cm}$ in one $(8.33 \%), 1.8 \mathrm{~cm}$ in one $(8.33 \%)$, $1.9 \mathrm{~cm}$ in one $(8.33 \%), 2.0 \mathrm{~cm}$ in one $(8.33 \%), 2.32 \mathrm{~cm}$ in one $(8.33 \%)$.

The percentage of cadavers with the median arcuate ligament touching the celiac trunk was $42.17 \%$ (35 cadavers) (Fig. 2).

It was observed that 29 out of 35 cadavers with the median arcuate ligament touching the celiac trunk had the right crus surrounding almost all the superior margin of the

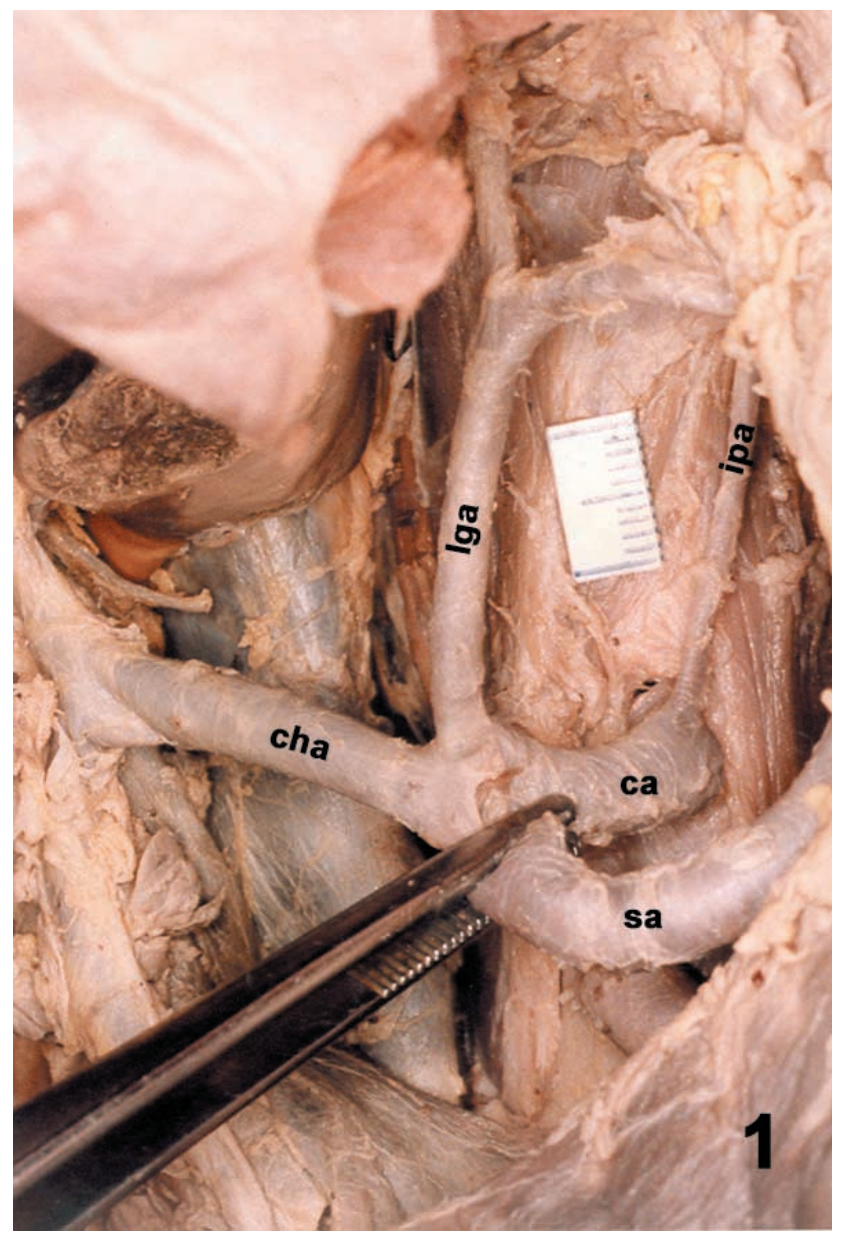

Fig. 1. Male. Adult. Celiac Trunk (ca); Left gastric artery (lga); Splenic artery (sa); Common hepatic artery (cha); Right crus (rc); Left crus (lc). Observe the median arcuate ligament $0.2 \mathrm{~cm}$ distant from the celiac trunk.

celiac trunk and the left crus maintaining contact with the lateral portion of it or surrounding it in some millimeters. In three other cases, it was seen that the right crus was surrounding the celiac trunk and the left one was distant from it; and, in three cases, the opposite occurred: the left crus was surrounding the celiac trunk and the right was maintained distant from it.

Also, the median arcuate ligament overlapped the celiac trunk in 36 cadavers (43.37\%) (Figs. 3 and 4).

The mean extension of the median arcuate ligament overlapping the celiac trunk was $0.42 \mathrm{~cm}$, maximum $1.0 \mathrm{~cm}$ and minimum $0.1 \mathrm{~cm}$. An overlap of $0.10 \mathrm{~cm}$ was observed in four $(11.11 \%), 0.15 \mathrm{~cm}$ in one $(2.78 \%), 0.20 \mathrm{~cm}$ in $11(30.56 \%), 0.30 \mathrm{~cm}$ in one $(2.78 \%), 0.40 \mathrm{~cm}$ in two $(5.56 \%)$, $0.50 \mathrm{~cm}$ in five $(13.89 \%), 0.52 \mathrm{~cm}$ in one $(2.78 \%), 0.55 \mathrm{~cm}$ in one $(2.78 \%), 0.60 \mathrm{~cm}$ in three $(8.33 \%), 0.63 \mathrm{~cm}$ in one 

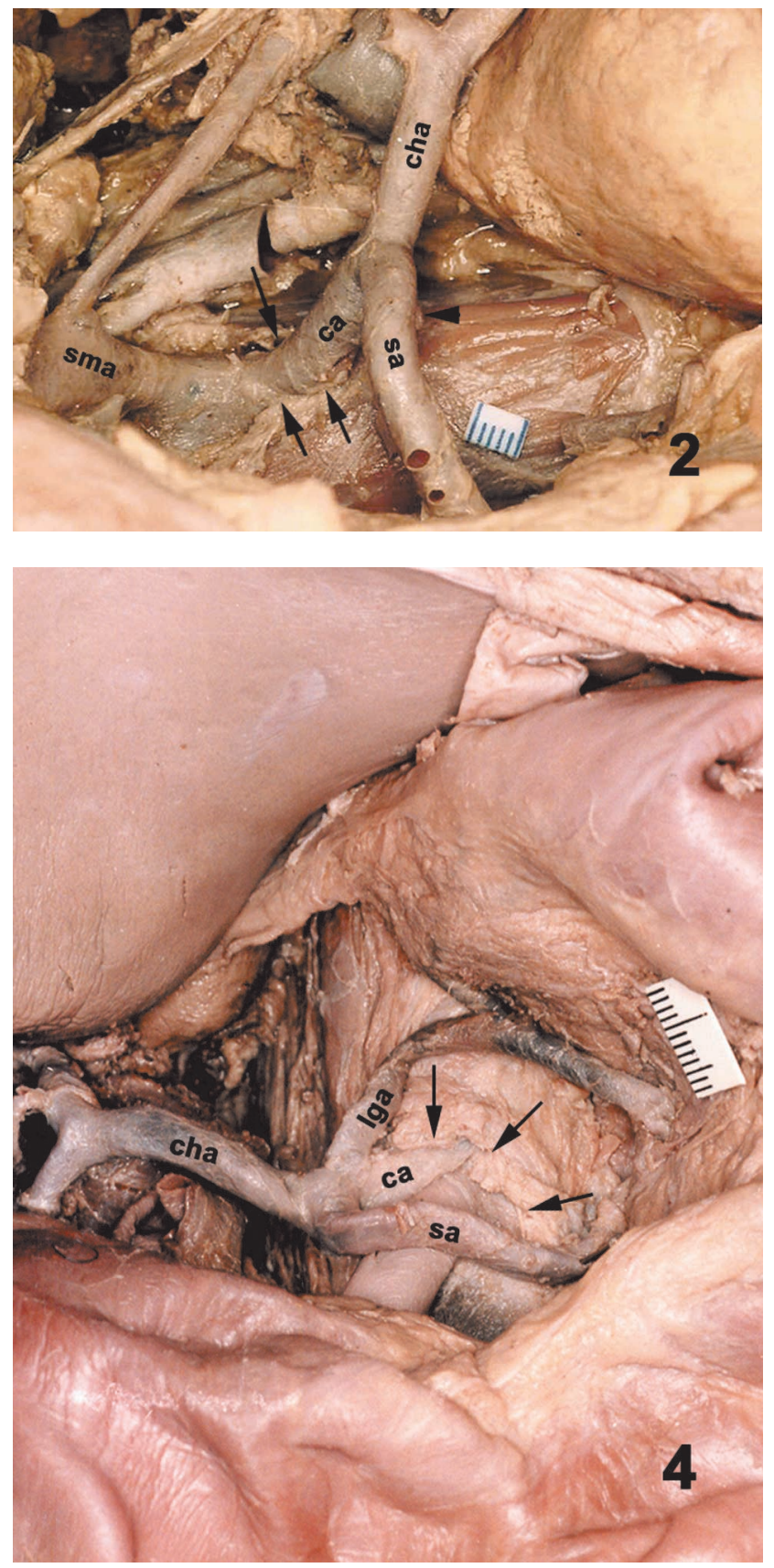

Fig. 2. Adult male. Celiac trunk (ca); splenic artery (sa); common hepatic artery (cha); left gastric artery (head of arrow); superior mesenteric artery (sma). Observe the median arcuate ligament touching the celiac trunk (arrows).

Fig. 3. Adult male. The median arcuate ligament (big arrows) was moved aside showing the celiac trunk (ca) with a "notch" (head of arrow) due to the median arcuate ligament. Left gastric artery (small arrow); splenic artery (sa); common hepatic artery (cha); superior mesenteric artery (sma).

Fig. 4. Adult male. Left gastric artery (lga); splenic artery (sa); common hepatic artery (cha). Median arcuate ligament (arrows).

Fig. 5. Adult male. Celiac trunk (ca) formed by splenic artery (sa) and common hepatic artery (cha). It is observed the initial segment of the left gastric artery (lga) under the median arcuate ligament (arrow).
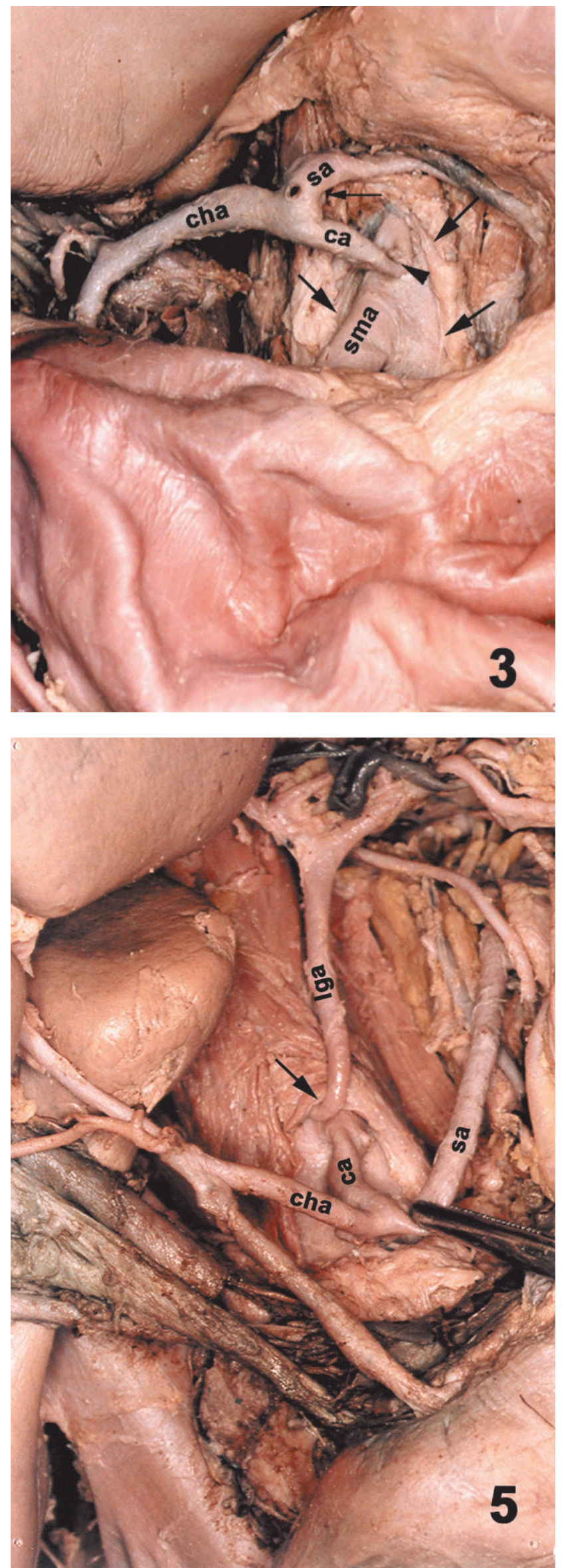


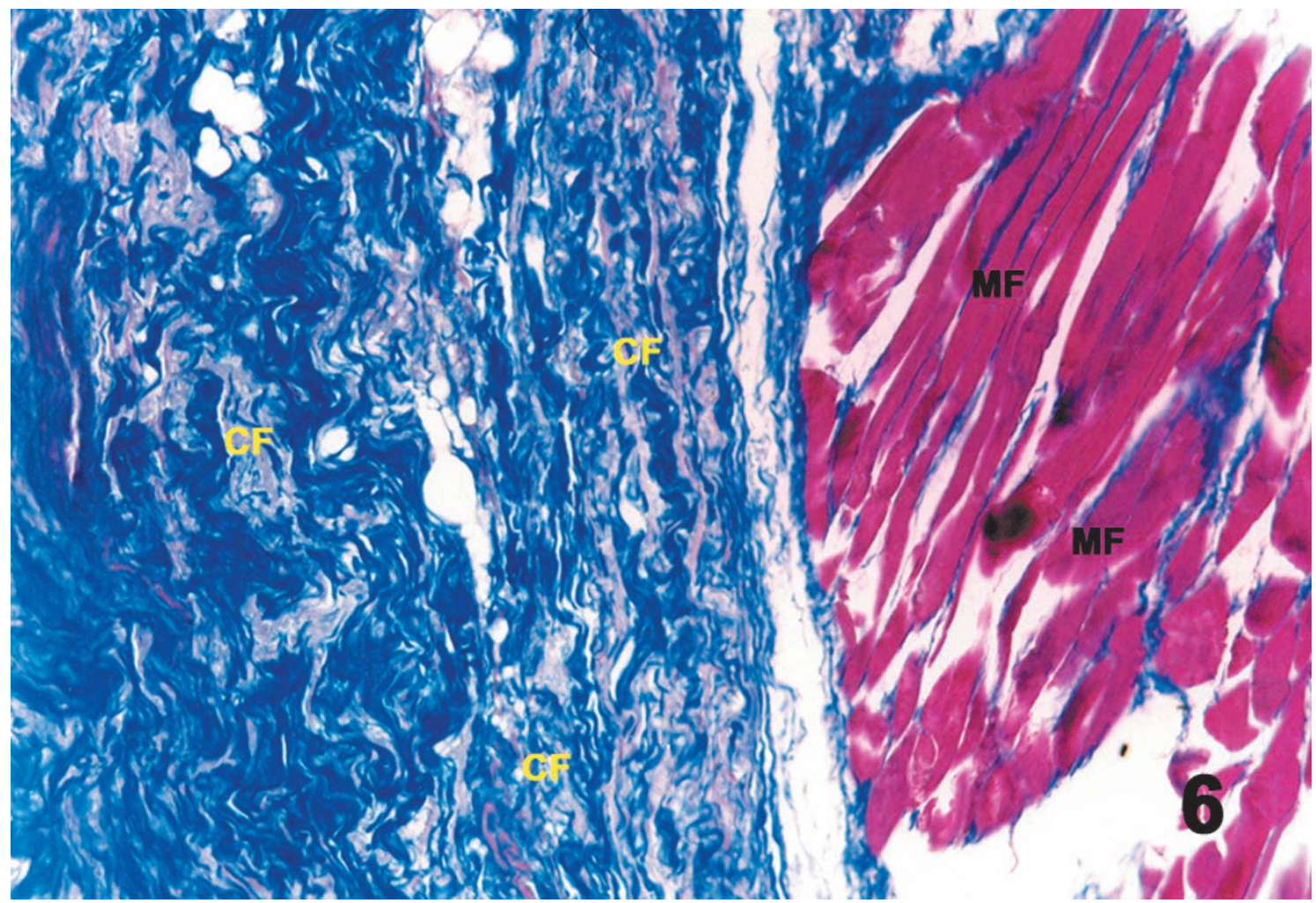

Fig. 6. Adult male. Photomicrography showing the median arcuate ligament of the diaphragm. It is observed the connective tissue rich in collagenous fibers (CF) and striated skeletal muscular fibers (MF). Masson's trichrome. $380 \mathrm{x}$.

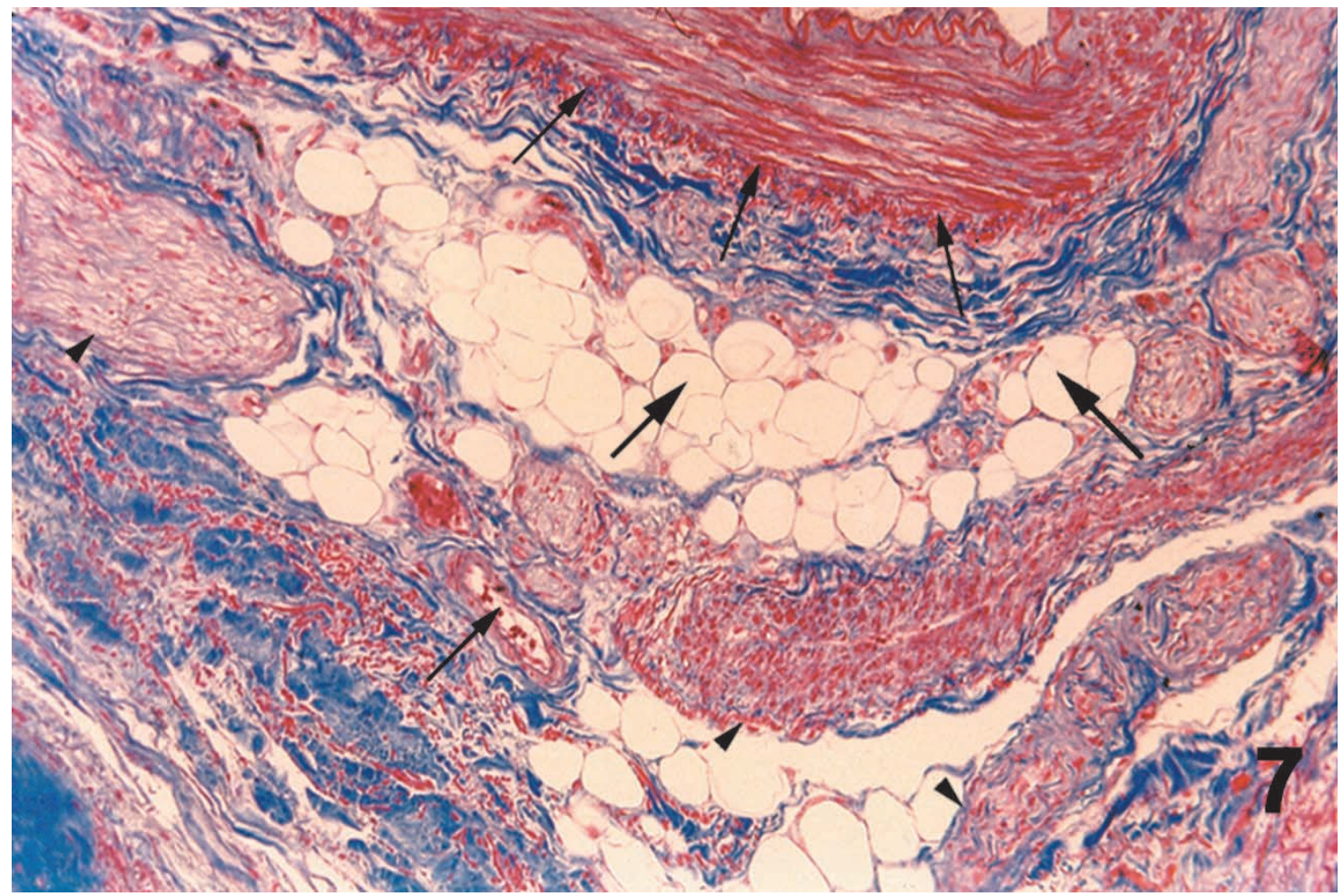

Fig. 7. Male. Adult. Photomicrography showing the median arcuate ligament of the diaphragm. Observe the connective tissue rich in adipose cells (big arrow), blood vessels (small arrow) and nerves (head of the arrow). Masson's trichrome. 380 x. 


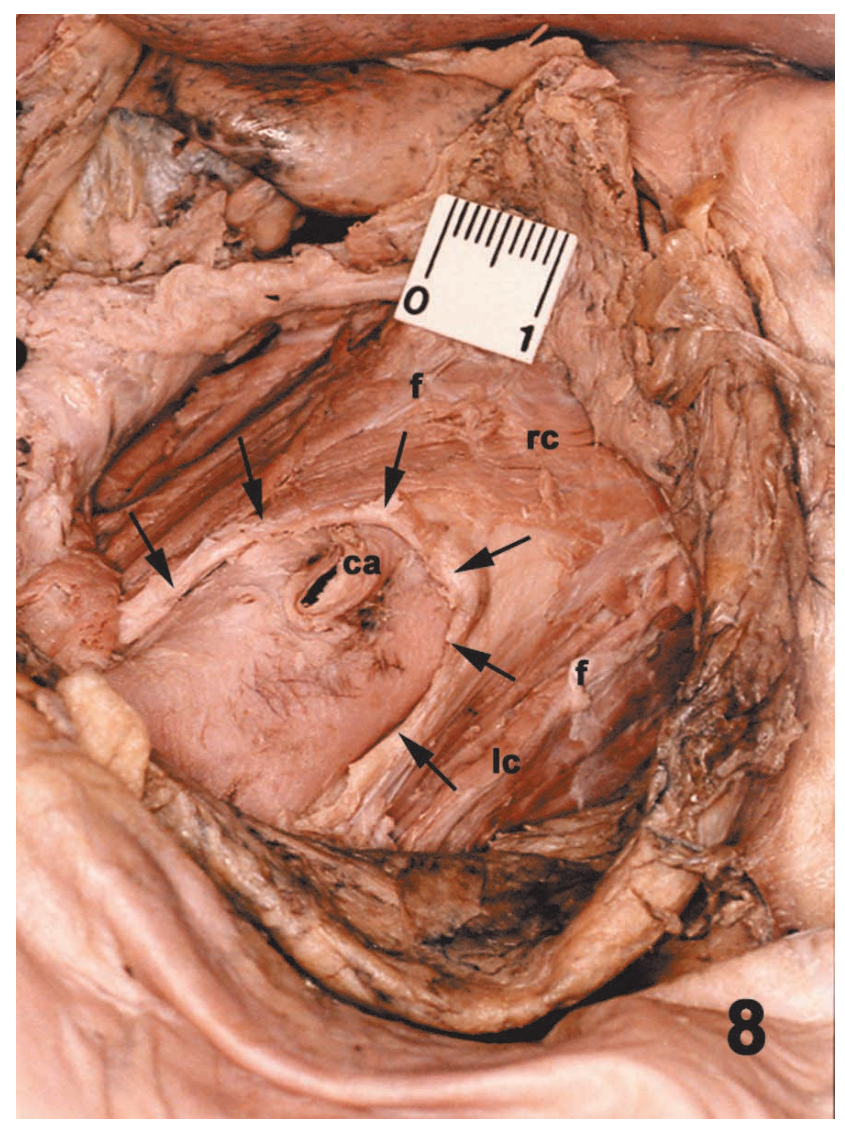

Fig. 8. Adult male. The celiac trunk (ca) was sectioned. Median arcuate ligament (arrows), right crus (rc), left crus (lc). The fascia (f) covering the crura and the median arcuate ligament was removed. Observe the median arcuate ligament in a triangle shape and ending as a fibrous ring (arrows).

(2.78\%), $0.70 \mathrm{~cm}$ in one (2.78\%), $0.75 \mathrm{~cm}$ in two (5.56\%), $0.90 \mathrm{~cm}$ in one $(2.78 \%), 1.0 \mathrm{~cm}$ in two $(5.56 \%)$. The most frequent overlap extension was $0.2 \mathrm{~cm}$. Only in two $(2.25 \%)$ cadavers overlap of the ligament was observed in the initial segment of the left gastric artery with an independent origin in aorta (Fig. 5).

Regarding the overlap relationship between the right or left crus of diaphragm on the celiac trunk, 36 cadavers presented overlap of this trunk by the left crus in five cases, with extension of 0.2 to $0.9 \mathrm{~cm}$, mean of $0.59 \mathrm{~cm}$. In eight cases, it was observed the right crus overlapping from 0.1 to $0.7 \mathrm{~cm}$, mean of $0.3 \mathrm{~cm}$. In the other 23 cadavers, both crura were covering the celiac trunk from 0.1 to $1 \mathrm{~cm}$, mean of $0.4 \mathrm{~cm}$.

Histological description of the median arcuate ligament of the diaphragm. Based on the histological analysis of the median arcuate ligament of the diaphragm, it was observed that it is consist of its lower region, that is, the inferior edge of the aortic hiatus towards the upper region of

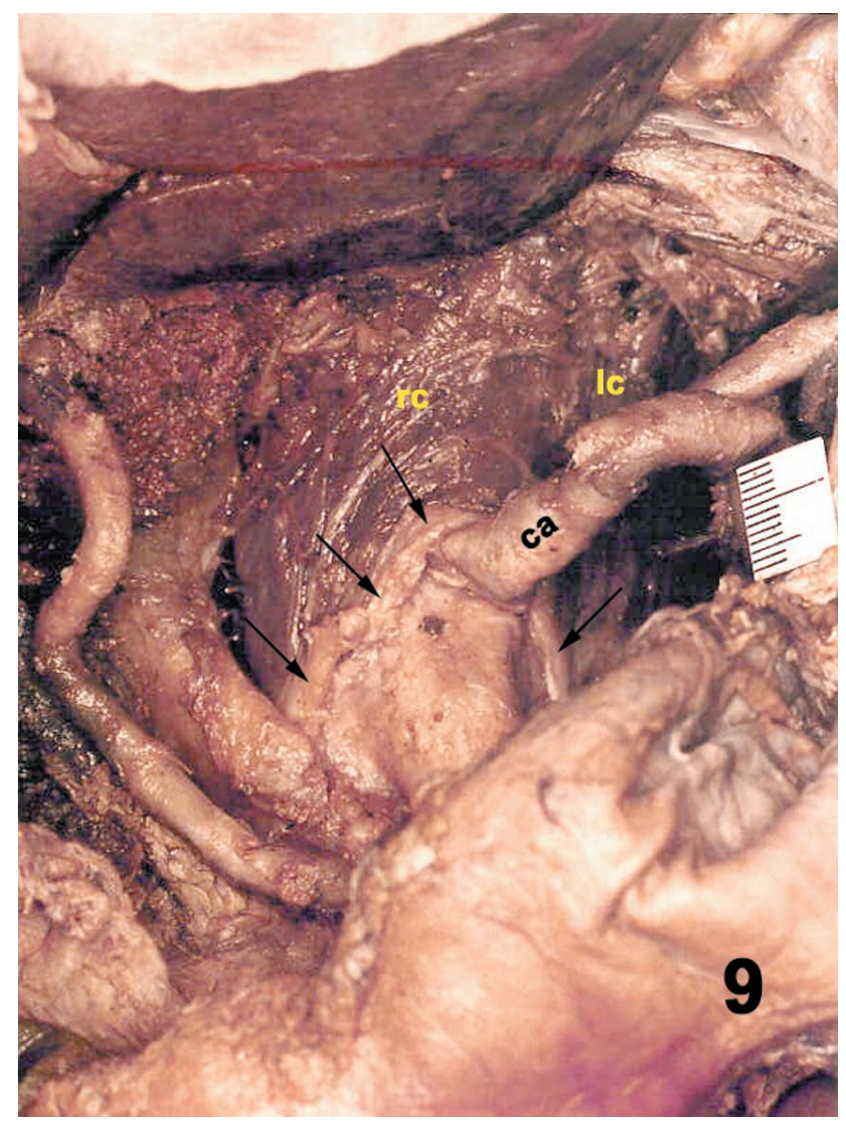

Fig. 9. Adult male. Celiac trunk (ca); right crus (rc). Left crus (lc). Observe the median arcuate ligament as a fibromuscular arciform structure (arrows).

the muscular fibers of the diaphragm crura, by thick layer of dense connective tissue rich in collagenous fibers and infiltrated by adipose cells, blood vessels of different calipers and several nervous filaments. Superiorly, continuing this layer, we found several muscular striated skeletal fibers intermingled by collagen fibers, emphasizing that these muscle fibers are covered by a rich connective tissue with collagenous fibers (dense connective tissue), which may have different thickness depending on the analyzed region (Figs. 6 and 7).

\section{DISCUSSION}

In the literature studies on the syndrome are limited to angiographies and surgery with lack of morphological data. Therefore, further specific researches, in dissected cadavers, on the celiac trunk behavior are needed in relation to the diaphragm crura and the median arcuate ligament. 
In the present study, by means of an anatomic study, we could observe the measures of positions that the median arcuate ligament may have in relation to the celiac trunk and to compare them with those obtained in the analyzed literature.

Angiographic studies during respiration process showed the dislocation of the median arcuate ligament, aorta and celiac trunk, resulting in a greater approximation between the celiac trunk and the median arcuate ligament in the expiration (Reuter, 1971; Stanley \& Fry and Reuter \& Bernstein, 1973). These studies led us to conclude that the position of the median arcuate ligament in relation to the celiac trunk does not correspond to those found in fixed cadavers or not.

In our study, the minimum measures registered in mensurations were: $0.1 \mathrm{~cm}$ for overlap of the median arcuate ligament and $0.2 \mathrm{~cm}$ for the distance between the median arcuate ligament and the ostium of the celiac trunk.

Our results revealed that the inferior edge of the median arcuate ligament remained distant from the celiac trunk in $14.46 \%$ out of the 83 cadavers (Fig. 1), differing from the findings of Brunet et al. (1993) who referred $45 \%$ of 140 cadavers and from George (1934) who observed $42.11 \%$ out of 38 cadavers. The mean distance between the celiac trunk and the median arcuate ligament was $0.94 \mathrm{~cm}$, differing from the findings of Brunet et al., who observed a distance of 3.4 $\mathrm{mm}$, on average, and similar to those of Joubaud et al., who reported a distance from 10 to $20 \mathrm{~mm}$.

The touch of the celiac trunk by the median arcuate ligament was observed in $42.17 \%$ of the cadavers, this result different from those found by Brunet et al. who noted in $55 \%$ and those $36.84 \%$ observed by George (Fig. 2).

The term "touch" here used means the contact between the median arcuate ligament and the origin of the celiac trunk.

In our series we could observe that in most of the cases the celiac trunk was surrounded by the right crus and it is explained by its greater size in relation to the left crus. In $43.37 \%$ of the cadavers, we observed that the median arcuate ligament was overlapping the celiac trunk, which is not in accordance to $21.05 \%$ mentioned by George and those $10 \%$ reported by Brunet et al. (Figs. 3 and 4).

Lindner \& Kemprud (1971) showed among 72 nonfixed cadavers, $20(26 \%)$ had the origin of the celiac trunk touching the free edge or below the median arcuate ligament, differing from the $71(85.54 \%)$ cadavers found in this study with the median arcuate ligament touching or overlapping the celiac trunk.

Regarding relationship of diaphragm crura and the celiac trunk we found the left crus covering the celiac trunk in five cadavers, in an extension of $0.59 \mathrm{~cm}$, on average, and the right crus covering $0.30 \mathrm{~cm}$, on average, in eight. This fact was identified by Tahery (1968); Balmes et al. (1971); Cornell (1971); Drèze et al. (1972) and Lawson \& Ochsner. These authors did not present numerical data.

Additionally to angiographies, several non-invasive methods, such as echo Doppler or pulsatile color flow Doppler imaging (Tridico et al.; De Pauw et al., 1992 and Sproat et al., 1993), computerized tomography (Loffeld et al.), digital subtraction angiography (Desmond \& Roberts), magnetic resonance angiography and the color duplex ultrasonography (Alehan \& Dogan), have been able to detect the celiac trunk compression syndrome. We cannot compare our results with these methods since they were not used in our study.

Several angiographic studies (Bobbio et al., 1967; Debray et al., 1967; Snyder et al.; Bobbio \& Zanella, 1971; Conti et al., 1973; Furnemont, 1974; Joubaud et al.; Mc Sherry, 1977; Langeron et al. and Mongelli et al., 1980) reported an overlap of the median arcuate ligament from 1 to $2 \mathrm{~cm}$ which is not in accordance with the real measures.

Some authors admit that the higher origin of the celiac trunk in the aorta, the lower insertion of the median arcuate ligament or both conditions may explain the anatomic anomaly of the celiac trunk in the compression syndrome (Hivet \& Lagadec; Warter et al., 1970b; Lindner \& Kemprud and Tridico et al.). According to Houdard et al. (1970) the fibromuscular hypertrophy is followed by an ectopy of the celiac trunk, which was originated some millimeters higher than normal position.

Although it was not our objective to study skeloctopy of the celiac trunk and the median arcuate ligament, we observed some variations in the position of the celiac trunk, sometimes in T12 and in others L1 or L2. Likewise, we observed a free edge of the median arcuate ligament in a more superior position. We are in accordance with the results found in the literature regarding the position of the celiac trunk between T12-L2 (Curl et al.; Stanley \& Fry and Warter et al., 1976). On the other hand, our results are not in accordance with those of Rubush et al. who found the celiac trunk in L3-L4.

Fadhli observed the celiac trunk $5 \mathrm{~cm}$ inside the thoracic cavity. In contrast to this finding, no similar case was found in our sample. 
Some exceptional cases reported the simultaneous compression of the celiac trunk and the superior mesenteric artery by the median arcuate ligament, which can be explained by the particular disposition of these arteries in the aorta. Their origins are close and, sometimes, the initial segments of both are juxtaposed (Watson \& Sadikali and Langeron et al.). The occurrence of a simultaneous compression was not found in our study.

There are controversies on the concept of the own structure, limits and types of the median arcuate ligament. In our study, in five cadavers it was observed the median arcuate ligament in a triangle shape interconnecting the two crura and with no skeleton muscular fibers on it and the basis covering the celiac trunk, finishing like a fibrous ring which formed the inferior margin of the diaphragm crura (Figs.1, 8). These observations are in accordance with those of Dunbar et al.; Bobbio et al.; Hivet \& Lagadec; Leger et al. (1970); Furnemont and Brandt \& Boley. In other cadavers, the median arcuate ligament was like a fibromuscular structure covering the celiac trunk, ending like a fibrous arch presenting a variable width of 1 to $2 \mathrm{~mm}$, (Fig. 9) or non identified, which is in accordance with reports of many authors mentioning the median arcuate ligament like a fibrous bridge, aciform and transversally displayed forming the inferior margin of the hiatus aorticus of the diaphragm (Debray \& Leymarios; Fadhli; Harjola; Harjola \& Lahtiharju, 1968; Marable et al., 1968; Cormier \& De La Fontaine; Edwards et al., 1970; Gautier-Benóit et al., 1970; Houdard et al.; Curl et al.; Di Marino et al., 1972; Drèze et al.; Conti et al.; Joubaud et al.; Houssin et al.; Langeron et al.; Daskalakis, 1982; and Bacourt et al.). We are not in accordance with Ruiz Liard et al. (1964) who mentioned the absence of this fibrous arch.

The median arcuate ligament also received the denomination of median crus but due to behavior of this structure and comparing it with other formations in the lumbar part of the diaphragm, for instance, the medial and lateral arcuate ligaments, we judged that the best denomination would be the median arcuate ligament as mentioned in the Nonima Anatomica (1984).

In the histological analysis of the median arcuate ligament, we could observed the presence of dense connective tissue with collagenous fibers infiltrated by adipose cells, blood vessels and nerves. Continuing to this structure, some muscular skeletal fibers intermingled by the dense connective tissue, blood vessels and adipose cells were detected. These findings are in accordance with those of Harjola \& Lahtiharju; Olivier et al.; Lindner \& Kemprud; Drèze et al. andVan De Berg et al. (1972).
Likewise, we are in accordance with Bobbio et al. when they reported that in the reciprocal anatomic relationship with the aortic hiatus we have the muscular fascia of the diaphragm, the aponeurotic formation completing it, the aorta and its branches, the celiac plexus showing an intermingling of ganglions and fibers, weaving a network between the two crura and one adipose tissue fulfilling the empty areas.

Many authors referred to the aortic hiatus as the real aortic channel (Ruiz Liard et al.; Bobbio, 1968 and Di Marino et al.). The denomination aortic channel is related to the complex formation, which converges upon the aortic orifice of the diaphragm, which has an elliptic shape with its greater axe superoinferiorly and anteroposteriorly displayed, thus favoring its transformation into a channel formed by arciform fibers of the median arcuate ligament (Bobbio et al., 1967).

We are in accordance with this denomination since the aorta crosses not only the hiatus, which is a limited space, but also a channel laterally formed by crura, posteriorly by the vertebra and anteriorly by the median arcuate ligament with a variable extension.

Regarding the fact that the compression is due to the median arcuate ligament and/or fibrosis of the celiac trunk or ganglion, in our opinion it is difficult to make any reference only to the median arcuate ligament without the plexus contribution. We agree with those authors who mentioned that during the surgical revascularization process of the celiac trunk, compressed by the median arcuate ligament, the section or exerese of the rich fibronervous celiac plexus, whose fibers are deep intermingled with those of the median arcuate ligament, to access this ligament is almost a need (Harjola \& Lahtiharju; Balmes et al. and Guibert et al., 1980).

The observation that the phreno-celiac disease might be associated to several morphological or metabolic abnormalities led some authors to conclude about the existence of a new clinical entity, denominated as phrenoceliac congenital syndrome (Warter et al., 1970a; Warter et al., 1973a, 1973c; Warter et al., 1973b and Warter et al., 1974).

It is worth emphasizing the importance to conduct a systematic research to detect the likelihood of intercurrentdiaphragmatic stenosis in individuals with congenital or hereditary anomalies or, if these conditions occurred we could consider the possibility of stenosis in the celiac trunk, mainly when we are dealing with children with some of these anomalies, considering that this 
phrenic-celiac syndrome was observed in some parental cases (Dondival \& Drèze, 1972; Drèze et al.; Van De Berg et al.; Warter et al., 1974 and Bech et al., 1994).

Considering the median arcuate ligament in the celiac trunk compression syndrome, the results of the present study are interesting since they contribute to enlighten morphology of this ligament. We believe that further studies are needed aiming characterization of syntopy of diaphragm crura and celiac trunk with the constitutional type, which may bring some light to understand this important nosological entity.

PETRELlA, S.; RODRIGUES, C. F. S.; SGROTT, E. A; FERNANDEZ, G. J. M.; MARQUES, S. R. \& PRATES, J. C. Relación del tronco celíaco con el ligamento arqueado mediano del diafragma. Int. J. Morphol., 24(2):263-274, 2006.

RESUMEN: En el presente trabajo se investigaron las posiciones del ligamento arqueado mediano con relación al tronco celíaco, y las medidas de sobreposición y distancia entre estas dos estructuras. Además, fueron realizadas medidas de algunas variables como la longitud y el diámetro del tronco celíaco, estudios histológicos de los pilares del diafragma y de su ligamento arqueado mediano.

Utilizamos 63 cadáveres fijados en solución de formalina al 10\% y 20 cadáveres no fijados, adultos, de ambos sexos. Las disecciones del área del tronco celíaco fueron realizadas después de disecar la cavidad peritoneal, en los laboratorios de la Disciplinas de Anatomía de la UNIFESP-EPM, UNILUS y UNISA, y durante las necropsias en los Servicios de Verificación de Óbitos de la UNIFESPEPM y USP, Brasil.

Para el análisis morfológico, a nivel de microscopía de luz, de tres cadáveres no fijados escogidos al azar, fueron retirados fragmentos del ligamento arqueado mediano de $0.5 \mathrm{~cm}$ de alto por $1.5 \mathrm{~cm}$ de largo. Luego fueron procesados según técnicas tradicionales de inclusión. Se efectuaron cortes de $5 \mu \mathrm{m}$, los cuales fueron teñidos con hematoxilina-eosina y tricrómico de Masson.

Los resultados obtenidos permitieron llegar a las siguientes conclusiones: 1) Las posiciones del ligamento arqueado mediano en el tronco celíaco fueron independientes del sexo. En $12(14.46 \%)$ de 83 cadáveres, se pudo observar al tronco celíaco distante del ligamento arqueado. En $35(42.17 \%)$ este ligamento era tangente al tronco celíaco y en 36 (43.37\%) se sobreponía a este vaso. El promedio de la distancia entre el ligamento arqueado mediano y el tronco celíaco fue de $0.94 \mathrm{~cm}$ y la de sobreposición $0.42 \mathrm{~cm} ; 2)$ los resultados histológicos del análisis del ligamento arqueado mediano mostraron al tejido conjuntivo denso, infiltrado por células adiposas, vasos sanguíneos y nervios. Fueron observadas fibras musculares estriadas, entremezcladas con fibras colágenas.

PALABRAS CLAVE: Tronco celíaco; Ligamentos; Síndrome; Diafragma; Enfermedad oclusiva arterial.

\section{REFERENCES}

Alehan, D. \& Dogan, O. F. A rare case: celiac artery compression syndrome in an asymptomatic child. $J$. Pediatr. Surg., 39 (4):645-7, 2004.

Bacourt, F.; Brun, J. G. \& Goeau-Brissonière, O. Compression associée du tronc coeliaque, de l'artère mésentérique supérieure et de l'aorte par le ligament arqué de diaphragm. Presse Med., 13:731-2, 1984.

Bacourt, F.; Goeau-Brissonnière, O. \& Koskas, F. Compression associé du tronc coeliaque et de l'artère meséntérique supérieure par le diaphragme. Chirurgie, 114:762-8, 1988.

Balmes, M.; Janbon, C.; Vergues, J. \& Baissus, C. Sténose extrinsèque du tronc coeliaque par le ligament arqué du diaphragme. Arch. Fr. Mal. Appar. Dig., 60:161, 1971.

Bech, F.; Loesberg, A.; Rosenblum, J.; Glagov, S. \& Gewertz,
B. L. Median arcuate ligament compression syndrome in monozygotics twins. J. Vasc. Surg., 19:934-8, 1994.

Bessot, M.; Fays, J.; Piccioli, R.; Boileau, F. \& Bauquet, J. Sténoses de l'artère hépatique. Chirurgie, 96:45766, 1970.

Bobbio, A. La sindrome del canale aortico del diaframma (Stenosi da compressione del tronco celiaco). Omnia Med., 46:595-608, 1968.

Bobbio, A. \& Zanella, E. Compression stenosis of the celiac axis (the aortic canal syndrome). Long term results of surgical decompression. Surg. Italy, 1:17682,1971

Bobbio, A.; Zanella, E. \& Chiampo, L. La stenosi da compressione del tronco celiaco. Minerva Chir., 22:1024-34, 1967. 
Brandt, L. J. \& Boley, S. J. Celiac axis compression syndrome. A critical review. Am. J. Dig. Dis., 23:63340, 1978.

Broussin, J.; Caille, J. M.; Basseau, J. P.; Grelet, P.; Diard, F. \& Bellet, M. Syndrome d'oblitération du tronc coeliaque par ligament arqué. J. Radiol. Electrol. Med. Nucl., 51:826-8, 1970.

Brunet, C.; Moutardier, V. \& Di Marino, V. La région dite du "bouton coelio-mésentérique", étude anatomochirurgicale. J. Chir. (Paris), 2:70-3, 1993.

Carey, J. P.; Stemmer, E. A. \& Connolly, J. E. Median arcuate ligament syndrome. Arch. Surg., 99:441-6, 1969.

Ciscato, J. G.; Burihan, E.; Miranda, F. Jr.; Kuhlmann, G.G.; Garcia, P. M. Claudificação abdominal - compressão extrínseca do tronco celíaco. Rev. Bras. Cardiovascular, 12 (3):164-73, 1976.

Colapinto, R. F.; McLoughlin, J. J. \& Weisbrod, G. L. The routine lateral aortogram and the celiac compression syndrome. Diagn. Radiol., 103: 557-63, 1972.

Conti, A.; Tateo, R.; Cacciatore, E.; Tuscano, G. El síndrome del ligamento arqueado. Angiología, 25:171-6, 1973.

Cormier, J. M. \& De La Fontaine, P. Sténose extrinsèque du tronc coeliaque. Chirurgie, 96:453-6, 1970.

Cornell, S.H. Severe stenosis of the celiac artery. Analysis of patients with and without symptons. Diagn. Radiol., 99: 311-6, 1971.

Croft, R. J.; Menon, G. P. \& Marston, A. Does “intestinal angina" exist? A critical study of obstructed visceral arteries. Br. J. Surg., 68: 316, 1981.

Curl, J. H.; Thompson, N.W. \& Stanley, J.C. Median arcuate ligament compression of the celiac and superior mesenteric arteries. Ann. Surg., 173:314-20, 1971.

Daily, P. O. \& Fogarty, T. J. Simplified revascularization of the celiac and superior mesenteric arteries. Am. J. Surg., 131:762-5, 1976.

Daskalakis, M. K. Celiac axis compression syndrome. Int. Surg., 67:442-4, 1982.

Debray, Ch. \& Leymarios, J. Les sténoses non athèromateuses des troncs artériels digestifs. Sem. Hôp. Paris, 39:2455-61, 1968.
Debray, C. H.; Leymarios, J.; Hardouin, J. P.; Cerf, M.; Paolaggi, J. A. \& Hernandez, C. L. Les oblitérations ostiales progressives des artères digestives. Aspects clinique et arteriographique. A propos de six cas. Press. Med., 75:691-6, 1967a.

De Pauw, M.; Voet, D.; Kunnen, M.; Barbier, F. \& Afschrift, M. Arcuate ligament syndrome mimicking celiac occlusion. Am. J. Gastroenterol., 87:1482-4, 1992.

Desmond, C. P. \& Roberts, S. K. Exercise-related abdominal pain as a manifestation of the median arcuate ligament syndrome. Scand. J. Gastroenterol, 39(12):1310-3, 2004.

Di Marino, V.; Tournigand, P.; Adhoute, B. \&Mercier, C. A propos des compressions extrinsèques du tronc coeliaque. J. Chir. (Paris), 104:289-306, 1972.

Dondival, P. \& Drèze, Ch. Sténose du tronc coeliaque chez une mère et sa fille par compression due au ligament arqué médian du diaphragme. J. Genet. Hum., 20:4667, 1972.

Dordoni, L.; Tshomba, Y.; Giacomelli, M.; Janello, A. M. \& Chiesa, R. Celiac artery compression syndrome. Suscessful laparoscopic treatment - a case report. Vasc. Endovascular Surg., 36 (4):317-21, 2002.

Drèze, Ch.; Dodinval, P.; Lombard, R.; Van De Berg, L.; Van De Berg, A.; Jacquet, N. \& Booz, G. Compression du tronc coeliaque par le ligament arqué du diaphragme. Sept observations dont deux premiéres familiales. Acta Gastroenterol. Belgica, 35:529-48, 1972.

Dunbar, D.; Molnar, W.; Beman, F. F. \& Marable, S. A. Compression of the celiac trunk and abdominal angina. Am. J. Roentgenol. Radium. Ther. Nucl. Med., 95:73144, 1965.

Edhag, O.; Hogstedt, A.; Kovamees, A. \&Werner, B. A case of severe compression of the coeliac artery. Acta Med. Scand., 201:589-91, 1977.

Edwards, A Coeliac axis compression syndrome. Proc. $R$. Soc. Med., 62:488-90, 1969.

Edwards, A. J.; Hamilton, J. D.; Nichol, W. D.; Taylor, G. W. \& Dawson, A.M. Experience with coeliac axis compression syndrome. Br. Med. J., 1:342-5, 1970.

Evans, W. E. Long-term evaluation of the celiac band syndrome. Surgery, 76:867-71, 1974. 
Fadhli, H. A. Congenital diaphragmatic obstrution of the aorta and the celiac artery. J. Thorac. Cardiovasc. Surg., $55: 431-3,1968$.

Furnemont, E. La stenose du tronc coeliaque par le ligament arque du diaphragme. A propos de deux observation. $J$. Belg. Radiol., 57:443-50, 1974.

Gautier-Benóit, C.; Luez, J.; L’Hermine, Cl.; Wurtz. A. \& Houlcke, M. Duodéno-pancréatectomie céphalique et sténose du tronc coeliaque. J. Chir. (Paris), 99:381-90, 1970.

George, R. Topography of the unpaired visceral branches of the abdominal aorta. J. Anat., 69:196-205, 1934.

Ghosn, P. B.; Rabbat, A. G.; Trudel, J.; D'Amico, P.; Lecours, R. \& Trudel, J. Celiac compression syndrome. Can. Surg., 25:377-9, 1982.

Guibert, B.; Braillon, G.; Croisille, M.; Contassot, J.C.; Mayer, B. \&Frecon, G. Sténose du tronc coeliaque par le ligament arqué. Lyon Chir., 76:321-5, 1980.

Harjola, P. T. Coeliac axis constriction and abdominal angina. Bull. Soc. Intern. Chir., 27:464-7, 1968.

Harjola, P. T. \& Lahtiharju, A. Celiac axis syndrome. Abdominal angina caused by external compression of the celiac artery. Am. J. Surg., 115:864-9, 1968.

Hivet, M. \& Lagadec, B. Compression du tronc coeliaque par le ligament arqué du diaphagme. Rev. Chir. Mal. Foie de la Rate e du Pâncreas, 45:129-34, 1970.

Houdard, Cl.; Carles, J. F.; Helenon, Ch. \& Boschet, P. A propos d'un cas de compression extrinseque du tronc coeliaque. J. Chir. (Paris), 99: 9-24, 1970.

Houssin, D.; Lecompte, Y. \& Bismuth, H. Compression de l'artere mésentérique supérieure et du tronc coeliaque par le ligament arqué médian. Ann. Chir., 33:71-6, 1979.

Huguet, J. F.; Deronzier, R.; Burelle, H.; Abignoli, A. M. \& Jouve, P. Les sténoses congénitales du tronc coeliaque. J. Radiol., 53:895-6, 1972.

International Anatomical Nomenclature Committe - Nomina anatomica. $5^{\mathrm{a}}$ ed. México, Medsi, 1984.

Joubaud, F.; Pillet, J. \& Boyer, J. Compression extrínseque du tronc coeliaque par ligament arqué du diaphragme. Sem. Hôp. Paris, 53:157-64, 1977.
Kokotsakis, J. N.; Lambidis, C. D.; Lioulias, A. G.; Skouteli, E.T.; Bastounis, E. A. \& Livesay, J. J. Celiac artery compression syndrome. Cardiovascular Surgery, 8 (3):219-22, 2000.

Langeron, P.; Becquet, R.; Puppinck, P.; Descamps, C. L. \& Sockeel, G. Double compression du tronc coeliaque et de la mésentérique supérieure par ligament arqué. Chirurgie, 106:127-31, 1980.

Lawson, J. D.; \& Ochsner, J.L. -Median arcuate ligament syndrome with severe two-vessel involvement. Arch. Surg., 119:226-7, 1984.

Leger, L.; Viguié, R.; Moullé, P. \& Dentan, Th. Sténose du tronc coeliaque. Chirurgie, 96:469-70, 1970.

Lindner, H. H. \& Kemprud, E. A clinicoanatomical study of the arcuate ligament of the diafragm. Arch. Surg., 103:600-5, 1971.

Loffeld, R. J. L. F.; Overtoom, H. A. J. M. \& Rauwerda, J.A. The celiac axis compression syndrome. Digestion, 56: 534-7, 1995.

Lord, R.S.A.; Stoney, R. J. \& Wylie, E. J. Coeliac-axis compression. Lancet, 2:795-8, 1968

Marable, S. A.; Kaplan, M. F.; Beman, F. \& Molnar, W. Celiac compression syndrome. Am. J. Surg., 115:97-102, 1968.

McSherry, J. A. Coeliac artery compression sydrome: can we believe our ears? J. R. Coll. Gén. Pract., 27:684-6, 1977.

Mongelli, D.; Pederzoli, P.; Serio, G.; Bassi, C.; Abrescia, F. \& Bertrand, C. Sindrome da compressione extrinseca del tronco celiaco (a proposito di 4 casi). Chir. Ital., 32: 1963-76, 1980.

Mulder, D.S.; Rubush, J.; Lawrence, M.S. Celiac axis compression syndrome. Can. J. Surg., 14: 122-6, 1971.

Olivier, C.; Rettori, R. \& Di Maria, G. Sténoses non athéromateuses et compressions du tronc coeliaque. Chirurgie, 96: 471-82, 1970.

Plate, G.; Eklöf, B. \& Vang, J. The celiac compression syndrome: myth or reality? Acta Chir. Scand., 147:2013, 1981 .

Reuter, S. R. Accentuation of celiac compression by the median arcuate ligament of the diaphragm during deep expiration. Diagn. Radiol., 98:561-4, 1971. 
Reuter, S. R. \& Bernstein, E.F. The anatomic basis for respiratory variation in median ligament compression of the celiac artery. Surgery, 73:381-5, 1973.

Roayaie, S.; Jossart, G.; Gitlitz, D.; Lamparello, P.; Hollier, L. \&Gargner, M. Laparoscopic release of celiac artery compression syndrome facilitated by laparoscopic ultrasound scanning to confirm restoration of flow. $J$. Vasc. Surg., 32:814-7, 2000.

Rogers, D. M.; Thompson, J. E.; Garrett, W.V.; Talkington, C.M. Mesenteric vascular problems. Ann. Surg., 195: 554-65, 1982.

Rubush, J. L. Celiac axis compression syndrome. Rev. Surg. Dis., 27:215-6, 1970.

Ruiz Liard, A.; Praderi, J. M. Z. \& Polletti, H. Pilares principales del diafragma. An. Fac. Med., 49:373-90, 1964.

Siegel, S. Estatística não paramétrica (para as ciêncais do comportamento). Mc Graw-Hill, São Paulo, 1976. 350p.

Snyder, M. A.; Mahoney, E. B. \& Rob, C.G. Symptomatic celiac artery stenosis due to constr2iction by the neurofibrous tissue of the celiac ganglion. Surgery, 61: 372-6, 1967.

Sproat, I. A.; Pozniak, M. A. \& Kennell, T.W. Us case of the day. Radiographics, 13:1400-2, 1993.

Stanley, J. C. \& Fry, W. J. Median arcuate ligament syndrome. Arch. Surg., 103:252-8, 1971.

Szilagyi, D. E.; Rian, R. L.; Elliott, J. P.; Smith, R. F. The celiac artery compression syndrome. Does it exist? Surgery, 72:849-63, 1972.

Tahery, S. A. Abdominal pain due to isolated narrowing of the celiac artery. Vasc. Dis., 5:90-5, 1968.

Terpstra, J. L. Intestinal angina secondary to compression of the coeliac axis. Arch. Chir. Néerl., 18:245-53, 1966.

Thevenet, A.; Domergue, J. \& Joyeux, A. Traitment chirurgical des sténoses du tronc coeliaque par ligament arqué du diaphragme. Chirurgie, 111:851-6, 1985.

Tridico, F.; Zan, S.; Bruno, F.; Suffat, P. P.; Morino, M.; Contessa, L.; Iozzia, C. \& Sorisio, V. La sindrome da compressione del tronco celiaco. Considerazioni su di un caso clinico. Min. Cardioangiol., 36:385-90, 1988.
Van De Berg, L.; Lombard, R.; Drèze, Ch.; Guffens, J.; Delvigne, J. \& Van De Berg, A. Traitement chirurgical des sténoses du tronc coeliaque. Acta Chir. Belg., 5:334-51, 1972.

Warter, J.; Kieny, R. \& Storck., D. Le syndrome de l'artere mesentèrique. Rev. Prat., 19:1891-911, 1969.

Warter, J.; Kieny, R.; Storck, D. \& Jeanmaire, H. Sténose diaphragmatique du tronc coeliaque. Guérison chirurgicale, la notion de maladie phréno-coeliaque. $J$. Med. (Strasbourg), 4:87-93, 1973a.

Warter, J.; Kieny, R.; Storck, D. \& Tongio, J. La maladie phréno-coeliaque. Considérations nosologiques (a propos de deux cas opérés avec succés). Bull. Acad. Natl. Med. (Paris), 157:28-34, 1973c.

Warter, J.; Storck, D.; Geisler, F. Contribution nouvelle au syndrome phréno-coeliaque congénitale; un cas d'hypoplasie rénale unilatérale associé à une sténose d'origine diaphragmatique du tronc coeliaque. Ann. Med. Intern., 124:657-61, 1973b.

Warter, J.; Storck, D.; Gillet, B. \& Tongio, J. Nature congénitale des sténoses par compression diaphragmatique du tronc celiaque. Nouvel argument en faveur de cette interprétation: les cas de deux soeurrs. $J$. Med. (Strasbourg), 5:369-75, 1974.

Warter, J.; Storck, D.; Kieny, R.; Tongio, J. La maladie phréno-coeliaque. Ann. Radiol., 19:361-70, 1976.

Warter, J.; Storck, D.; Kieny, R. \& Tongio, J. Sténoses congénitales du tronc coeliaque. Arch. Fr. Mal. Appar. Dig., 59:765-80, 1970a.

Warter, J.; Storck, D.; Kieny, R.; Tongio, J. \& Warter, P. Aspects radiologiques des sténoses du tronc coeliaque. J. Radiol. Electrol., 51:721-30, 1970b.

Watson, W. C. \& Sadikali, F. Celiac axis compression. Experience with 20 patient and a critical appraisal of the syndrome. Ann. Intern. Med., 86:278-84, 1977.

Watt, J. K. Celiac axis stenosis. Scott. Med. J., 17:295-8, 1972.

Correspondence to:

Prof. Dra. Selma Petrella

Rua Rio Grande, 180 apto. 62

Săo Paulo - Vila Mariana

CEP 04018-000

São Paulo - BRASIL.

Email:petrellaselma@ig.com.6r

Received : 14-10-2005 Accepted: 22-03-2006 